\title{
The Effectiveness of Writing Journal and Feedback on Increasing \\ Writing Proficiency at University Students
}

\author{
Ninik Farikha \\ refairy.nf@gmail.com
}

\begin{abstract}
The practice of giving feedback in teaching and learning process seems to be unclear. Unclear is an inconsistent feedback given by the teacher during teaching learning process. Teacher rarely gave the evaluation because giving feedback will be time-consuming. Teacher used students' task sheet instantly. Teachers need to check the students' work and give the feedback to students' task. This way makes students aware that something "wrong" appears and they need to consider it to their improvement. This study intends to investigate the difference between students' achievement in writing proficiency who are taught by using writing journal technique and given feedback and those who are not. The research design used in this research was quasi experimental design. Experimental design is the conceptual outline in doing experiment. In this experimental design, the researcher used two English Program classes of IAIN Kediri. First class was experimental class which is treated using writing journal and giving feedback while the second class was control class which is not treated using writing journal and giving feedback. The results revealed that using writing journal technique in learning was effective to increase the students' writing ability. It was good technique to improve students' ability in writing proficiency.
\end{abstract}

Keywords: writing journal, feedback, writing proficiency.

\section{Introduction}

Writing as one of the four basic language skills has an important role in communicating a message to a reader for a purpose. Through writing, the writer can explain or describe something; as a result people miles away from can get information by reading the written message. Writing can also help the students who have a problem in speaking. Ghaitz (2002:1) stated that writing is a complex process that allows writer to explore thought and ideas, and make them visible and concrete. Writing encourages thinking and learning for it motivates communication and reflection. When thought are written down, ides can be examined, considered, added to, rearranged, and changed. For EFL learners, writing in English is a very complex process. Among the four skills, writing is regarded as the most difficult skill. The difficulty lies not only in generating and organizing ideas, but also in putting down the ideas into a readable text. The skills involved in writing are highly complex. Foreign language writers have to pay attention to higher level skill of 
planning and organizing as well as lower level skills of spelling, punctuation, and word choice.

The difficulty even becomes bigger if their language proficiency is weak.

Teaching means as a teacher's effort to make the students enjoy in learning English with good material, good technique and good media. And then teaching writing means guiding the students in process of creating communication in which students are able to express the meaning or message in a clear way. Hadfield (2008) wrote that while teaching writing, we can show the learners how to produce a particular text type, for example a thank you letter, a business report, or an article. By providing examples of the type of the text and helping the learners to see how they are structured, this is called genre- based writing. We can also focus on the stages a writer goes through to procedure text for example guided- writing, and free writing.

Teaching writing can be conducted successfully at EFL classroom if teacher can select the best method for teaching it. Right selecting of the best method can influence on students' achievement in writing proficiency. The teacher should recognize the students' need of writing. Knowing the students' need encourages the teacher to think what method can be implemented to the students. Brown (2001) argued that other difficulties which are faced by students in mastering writing skill are; firstly the process of writing request an entire different set of competencies and fundamentally different from speaking. Secondly, written results are often the result of thinking, drafting, and revising procedures that require specialized skills, skills that are not every speaker develops naturally. Thirdly, Hammer (2007) stated that many students either think or say that they cannot, or do not want to write because they lack of confident, think it is boring, and believe they have " nothing to say ".

From the opinion above, teacher should think how to make the students like writing because it is necessary for the students to improve their motivation of writing. When they students fond of writing, it will be easier for them to produce an essay. It depends on the students' mood. If the students' mood is good, it will be easier to produce students 'writing. Thus, the teacher should apply the appropriate method given to the students. Writing activity needs habit. The activity should make it habit. "Practice makes perfect", this utterance inspires the writer to explore more about the writing method. The writer believes that habitual writing makes the students writing proficiency becomes higher. The writer chooses writing diary becomes an appropriate way to teach writing. 
Writing diary is conducted regularly by the students, by this method students get used to writing an essay. Therefore, this activity is joyful, and students feel excited.

On the other hand, the practice of giving feedback in Indonesia seems to be unclear. Unclear is an inconsistent feedback given by the teacher during teaching learning process. The students never got the written evaluation of their task. Teacher rarely gave the evaluation because giving feedback will be time-consuming. Teacher used students' task sheet instantly. Teachers need to check the students' work and give the feedback to students' task. This way makes students aware that something "wrong" appears and they need to consider it to their improvement.

According to Hattie and Temperley (2007) effective feedback should provide information that helps students to see "where they are going" (learning goals); feedback information that tells students " how they are going", and feed forward information that points out to students " where to go next". It means that the feedback which is given to students should give a measured data. The teacher should give a clear information about the goal of teaching learning process, especially in writing, then teacher should show how to solve the problem of students had, and the last, teacher will accompany students to go to the next step which shows an improvement and achievement of students' work. According to Hattie and Timperley (2007) in their research from University of Auckland. It supports the theory of feedback for this thesis. The research states that feedback model stresses teachers if they want to teach effectively. They need to undertake effective instruction. The better for a teacher is providing elaborations through instruction than providing feedback on poorly understood concepts. So, for the most difficult topic or material, it is better that the researcher uses feedback to students' performance or product. According to Pertiwi in her research (2010)“Teacher's Feedback on Students' Descriptive Texts: A Case Study in a Junior High School in Bandung" stated that The result of this research was most students tended to respond positively towards the feedback provided by the teacher, and they considered it helpful for them to make better writing. This research has similarity with this thesis in variable giving feedback. It seemed that those previous research stated that giving feedback to students' product is helpful the students to improve their ability in writing.

Most of teachers in school and college give the students' feedback only score for their product without giving clear correction on their products. So, the students do not know what their 
mistakes in their work. Therefore, teacher must give clear feedback to students' work in order that students can correct their mistakes and fix it appropriately. It is helpful to students by knowing their mistakes and the students will remember the mistakes and know how to correct it when they write another writing product. Looking at students in the classroom that have different background of English, they get difficulty to implement their English skills in the classroom, even they have to follow English curriculum in their university that it is a little bit difficult for them to follow the curriculum because they are lack of English knowledge. Moreover, when the students implement writing skill, they get difficult to create or write their thought and idea into writing. Therefore, teacher in the classroom should think how to teach the students appropriately so that the target of the study is reached. Teacher should choose the correct and appropriate method or technique to teach the students in the classroom, especially in teaching writing. Knowing that fact, writing journal can be implemented to the classroom in teaching writing. Looking at from the previous study that conducted the research about writing journal and feedback, this technique can help the students improving their ability. But all of them only used two variables to conduct the research. From this, the researcher wants to blend three variables to conduct the research in order that students can produce writing much better. The researcher wants to verify the previous research about writing journal and feedback on increasing students' ability whether this writing journal technique and feedback is effective or not implemented into the researcher's classroom in IAIN Kediri especially in application class.

To accomplish this aim, This study intends to answer the question, "Do the students who are taught by using writing journal technique and feedback have better achievement in writing proficiency than the students who are not taught by using writing journal and feedback?". The Hypothesis of the study is the students who are taught by writing journal technique and feedback have better achievement in writing proficiency than the students who are not taught by writing journal technique and feedback. The study is focused on writing journal; the content is telling about the student's experience in that past, it is free writing. Writing proficiency here is limited into recount text, telling about past experiences. Giving indirect feedback to students' journal, involves the grammar: appropriate word; and the content 
In order to have a better understanding and to avoid misinterpretation about the terms used in this research, it is necessary for the research to explain them in details as follows:

First, Writing proficiency is the skill and ability to produce and share information of thought, and ideas in written form of paragraph. It is focused on recount text. It is measured by three components; they are focus/organization, elaboration/support/style, and grammar/usage/and mechanics. It is written in 3-4 paragraphs, it consists of 300-500 words in 90minutes. Second, Writing journal means the students write their experience on a notebook regularly, it aims to habituate students to write their experience at past on students' note book. It is written at home as homework. It is submitted once a week, the students write three events in a week and submit it to the teacher and the teacher gives feedback. Third, Feedback is one of some techniques which were used to improve students' writing skill. Feedback here means giving correction to the students' journal writing. The feedback consists of grammatical correction, the use of word, and the content of the journal. And sometimes teacher gives a little bit motivation on students' journal when they need it. It can make the relationship closer between teacher and students. Fourth, Increasing students' writing proficiency is making some students better in their score of writing skill of English. Writing skill is one of some skills that is taught in school. The other skills are listening, speaking, and reading. Writing itself is the most difficult skill that should be learnt by students because students should pass some process of writing which need long time to get the best result. By using feedback, students will do their task easily, and their score of writing will improve.

\section{Literature Review}

Teaching means as a teacher's effort to make the students enjoy in learning English with good material, good technique and good media. And then teaching writing means guiding the students in process of creating communication in which students are able to express the meaning or message in a clear way. Hadfield (2008) wrote that while teaching writing, we can show the learners how to produce a particular text type, for example a thank you letter, a business report, or an article. By providing examples of the type of the text and helping the learners to see how they are 
structured, this is called genre- based writing. We can also focus on the stages a writer goes through to procedure text for example guided- writing, and free writing.

Looking at learners' written work gives us a good opportunity to assess students' progress and to give them helpful feedback on their error. But be careful how we correct, it can be very discouraging to learners when a piece of work comes back covered by a red ink. You will have to decide which errors are the most important, and mark these only. It is also valuable for the learner to have to think out what the mistake was and correct it him / herself. For these reasons it is useful to have a correction code. Underline the place where the error occurs and put a note or symbol in the margin saying what kind of error it is, for example, a mistake in a verb tense, or a spelling mistake.

Some commonly used symbols in correction codes

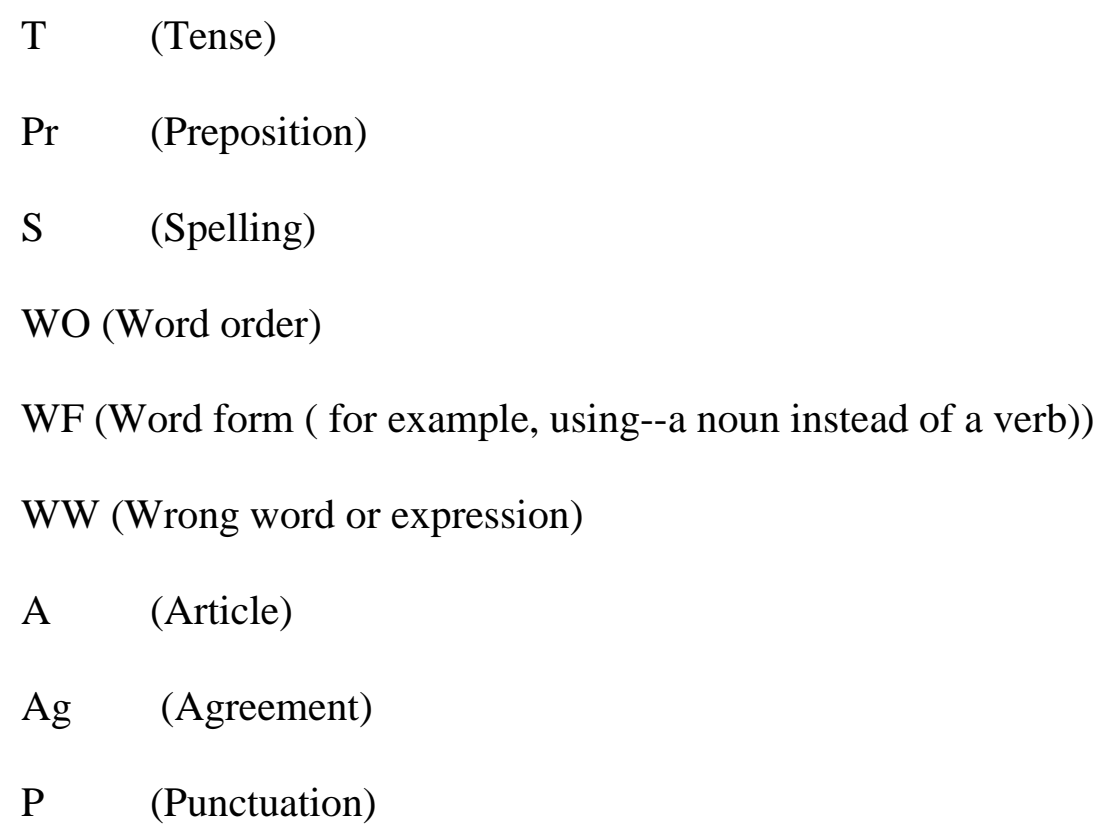

Feedback is information provided by an agent (e.g. teacher, peer, book, parents, and expertise) regarding aspects of one's performance or understanding. Feedback has three major questions, those are; a) where am I going? b) How am I going? And c) Where to next?. According to Hattie and Timperley (2007), to be effective, feedback needs to be clear, purposeful, meaningful, and compatible with students' prior knowledge and to provide logical connection. Teacher feedback should be both Written Feedback and Verbal Feedback. Written Feedback consists of two based, they are (1) Criterion-based, and (2) Reader-based.

Criterion-based feedback indicates how well the writing meets the criteria on scoring guides or rubric. This feedback refers to features such as the appropriateness of the idea and 
information, the level of detail, and the chosen point of view. It also addresses to clarify of communication through the organization of ideas and use of writing convention and effective language. This feedback is most useful when students have previously given the assessment criteria and have clear understanding the criteria.

Reader-based feedback reflects the reader's experience of writing. Feedback identifies images visualized, and emotions evoked. It describes how the writing makes the reader feel and summarizes what the writing says to reader. Because writing is a form of communication, student writers benefit from reader-based feedback, as they get a sense of how well their writing achieves the intended communicative purpose. Reader-based feedback on writing is having on a peer audience. Peer feedback helps to develop student writers' sense of audience. In classroom where desks are arranged so that students can easily talk to each other, students may ask peers for feedback spontaneously, as they feel it is needed.

Verbal feedback may be given as teachers circulate around the room while students are writing. Students may request their teachers' input, or teachers may offer a commendation or suggestion as students draft and revise their writing. Students and teacher also may have some conference. On that situation, students sign up to meet the teachers if they are ready for feedback. This conference can be an effective way because it provides individualized instruction for students to gather information about student's thinking and process of writing. Again, students-teachers conference or we called with verbal feedback is most effective when there is a dialogue between students and teacher. The students may ask for help in a particular area. Peterson (2011) stated that to support students' sense of ownership of their writing, feedback should be designed as follows:be given in the spirit of showing student writers the positive effects their writing has on readers, identify potential areas where students may revise their writing to clarify meaning or more fully engage readers, take the form suggestions, observations, and open-ended questions, rather than instructions and criticism.

If student writers will not be able to benefits from feedback that they do not fully understand. We can invite students to: explain their interpretations of the feedback and speculate what they might do to use the feedback (explaining their plans for using the feedback may also 
strengthen commitment to improving their writing), submit a "revise-and-resubmit" letter, explaining how the feedback has been addressed, or providing a rationale for disregarding.

Feedback's implication, however, is not "the answer"; rather it is one of "powerful answer". The better, teacher provides elaboration through instruction than provides feedback on poorly understood concepts. If feedback is directed at the right level, it can assist students to comprehend, engage, or develop effective strategies to process the information intended to be learned. To be effective, feedback needs to be clear, purposeful, meaningful, and compatible with students' prior knowledge. It also needs to prompt active information processing on the part of learners, have low task complexity, relate to specific and clear goals, and threat to the person at the self-level.

When feedback is combined with effective instruction in classrooms, it can be very powerful in enhancing learning. As Kluger and DeNisi (1996) noted that feedback intervention provided for a familiar task, containing cues that support learning, attracting intervention to feedback-standard discrepancies at the task level, and void of cues that direct attention to the self is likely to yield impressive gains in students' performance.

O’Malley and Piece (1996) assert that these four types of knowledge used in writing have at least two implications for writing assessment with EFL learners. first, writing assessment should evaluate more aspects of writing than just mechanic and grammar. Second, writing assessment should capture some of the processes and complexity involved in writing so that teachers can know in which aspects of the writing process students are having difficulty. Referring to this, there are two kinds of assessment, which can be used in assessing students' writing. They are process assessment and product assessment.

Process assessment is a kind of on going assessment used to keep track of students' progress in writing or to monitor thestudents' progress in writing in which counting the number (score) of the composition is not regarded. Process assessment is designed to probe how the students write, the decision they make as they write, the strategies they use. Therefore, the aim of process assessment is to give information about the students' performance such as how far the students' progress in writing and whether any change is needed in the way of teaching strategy or not. 
Product assessment focuses on assessing the students' final composition. Dealing with writing product, it can be assessed through employing some method of scoring. There are three types of rating scales generally used in scoring writing. They are holistic, primary trait, and analytic scoring.

Holistic scoring uses a variety of criteria to produce a single score. The specific criteria selected depend on local instructional programs and language objective. The rational for using a holistic scoring system is that the total quality of written text is more than the sum of its components. Writing is viewed as an integrated whole. The advantage of this scoring method is it can be finished quickly. The disadvantage is it can be subjective.

The last type of rating scale uses analytic scoring. Different from the holistic system, analytic scales separate the features of a composition into components. The separate components are sometimes given different weights to reflect their importance in instruction. Two advantages of this type of rubric are in providing feedback to students on specific aspects of their writing and giving teachers diagnostics information for planning instruction Perkins(in O’Malley\&Pierce, 1996).

Another special advantage of analytic scoring with EFL learners is in providing positive feedback on components of writing on which they have progressed most rapidly. Comparing those three scoring systems, it seems that analytic scoring tended to be closer to the criteria used in process writing. According to Hughes (2003), he stated, there were three parts to test writing. First, representative task, it means that the writing tasks are representative to be able to expect the students' performance and they should be identified in the test specification. The specification of content presented such as operations, types of text, addresses, length of texts, topics, dialect and style. Second, the tasks should elicit valid samples of writing; it means that the task should represent the students' ability. Third, the sample of writing can and will be scored validly and reliably.

Some previous studies that support the contain of this Article The first is research entitled “The Power of Feedback" by John Hattie and Helen Timperley(2007) from University of Auckland. It supports the theory of feedback for this thesis. The research states that feedback model stresses teachers if they want to teach effectively. They need to undertake effective instruction. The better for a teacher is providing elaborations through instruction than providing feedback on poorly 
understood concepts.So, for the most difficult topic or material, it is better that the researcher uses feedback to students' performance or product.

The second is research journal by Andriana J. Berlangga(2008) from Manchester University, United Kingdom, by the title "Language Technologies to Support Formative Feedback". Berlangga (2008) states that obtaining information of feedback will be time consuming task that most tutors cannot give, so developing a support tool which provides tutors and learners' progress is important. It means that the teacher has the hard task in giving feedback to the students. So, the teacher needs help to give feedback to the especially in language term. Therefore, there are some language technologies that can help the teacher in giving feedback. This research matches this thesis in variable giving feedback. But, the differencesare the design and approach used, this research uses quantitative experimental design but the previous research uses qualitative descriptive design.

The third journal is under the title "Improving Descriptive Writing Skills Using BlogBased Peer Feedback" written by Ali Hoevidi, Kerman Institute, Iran. The research was done in intermediate students. The students wrote essay of descriptive text then they posted the essay on blog. The other students corrected the classmate's essay based on a scoring rubric. The analysis of research found that peer feedback had positive impact on grammar and word choice of students. This research has similarity with this thesis in variable giving feedback. But, the differences are the design and approach used, this research uses quantitative experimental design but the previous research uses classroom action research. The material is also different. The previous research uses descriptive as the material, but this research uses recount text.

The fourth research came from Universitas Pendidikan Indonesia, Bandung, Indonesia. The title of research was “Teacher's Feedback on Students' Descriptive Texts: A Case Study in a Junior High School in Bandung”. The writer's name is Indri Eka Pertiwi. The result of this research was most students tended to respond positively towards the feedback provided by the teacher, and they considered it helpful for them to make better writing. This research has similarity with this thesis in variable giving feedback. But, the differences are the design and approach used, this research uses quantitative experimental design but the previous research uses case study. The material is also different. The previous research uses descriptive as the material, but this research uses recount text. 
Then, the subject used is senior high school students, but this research takes first year students of college.

The fifth research came from Universtitasnegeri Semarang. The title of this research was Improving Students' Ability in Writing Recount Text by Using Journal Writing (2012). The writer's name is SitiAlfiyah. The result of this research is effective using journal writing to improve students' ability in writing recount text. The similarity of two researches are using same technique to improve or increase students' achievement in writing recount text by using writing journal technique. The differentiates between them are the previous research did not use feedback to control students' writing and the previous research did not use two classes to do the research. It can be said that the previous research used pre-experimental research design, while in this research, researcher uses quasi-experimental research design.

\section{Method}

Researcher used quasi-experimental as research design because the researcher used two groups in this research. Kerlinger (1970) refers to quasi-experimental situation as 'compromise design', an apt description when applied to much educational research where the random selection or random assignment of schools and classrooms is quite impracticable. The research design can be represented as:

\section{\begin{tabular}{llll} 
Experimental & $\mathrm{O} 1$ & $\mathrm{X}$ & $\mathrm{O} 2$ \\
\hline
\end{tabular}}

Control $\quad \mathrm{O} 1 \quad \mathrm{O} 2$

This design took some subjects of study from certain population into two groups. One group became experimental group, and another group became control group. The researcher should guarantee that the subjects of study in both of groups had equal proficiency in writing. It means that all subjects before having treatment and no treatment had same ability in writing proficiency. Experimental group got variable of treatment $\mathrm{T}$ in certain period of time, and then those two groups have equally final measurement of writing proficiency. The difference that occurred was considered 
from variable of treatment $\mathrm{T}$. Therefore, the result of post-test was valid parameter to measure the improvement of students' writing proficiency.

This study used quasi-experimental design research, so there were two classes as subject of the study. The researcher was given authority to choose only two classes in application class of IAIN Kediri. There were 20 classes of second semester, and the researcher chose 1A and 1B became the subject of the study. It was chosen from covariate. The covariate was seen from the score of UAS from first semester. There were 26 students in $1 \mathrm{~A}$ and 20 students in $1 \mathrm{~B}$, so the total was 46 students. 1A became experimental class while 1B became control class.

This experimental research was settled through some procedures of experiment. Those were doing the treatments in experimental group and giving post-test in experimental group and control group. The researcher did not give pre-test because the researcher had known the ability of those two groups from the mean score of UAS. So, it was not necessary to give those two groups pre-test, the researcher gave them the next steps directly.

\subsubsection{Doing the Treatment}

The researcher tried to keep all conditions in both groups remain same; except one thing, that was, experimental group got 2 variables of treatment $\mathrm{T}$ in certain period of time but control group did not. The lesson plans were made same between experimental group and control group. The teacher explained and taught in the classroom by applying conventionalmethod (see appendix 3), the only one which made it different between experimental and control group was for experimental group was be given homework to write journal and for control group did not.

Experimental group was be given treatment as what the researcher planned. The students were be asked to write journal at home as their homework for 6 weeks. They wrote each week minimum four moments. The students wrote their journal in their notebook. It was free writing; they could write whatever they wanted about anything. After doing that, they submitted their notebook to the teacher and the teacher gave feedback to them. After giving feedback, the teacher returned the notebook back to the students, the students corrected their writing and they started to write again and so on until they did that for six weeks.

A test should have validity in the sense that if it measure what it intends to be measured (Sugiono,2008:121). The validity of the test always depends on situation and purpose of the test 
used. A test that is valid for situation may not be valid for other situation, and the purpose of using test is also a factor in showing validity. In this research, content validity showed the validity of the instrument.

According to Hughes (2003), there are three kinds of validity, they are content validity, criterion-related validity and, construct validity. Content validity here means that a test is valid when it represents the goal of the ability targeted. In this research, the goal of the test was to measure whether the students can write and create recount text so the researcher made the test that asked the students to write recount text based on the topics provided by the teacher. In this case, the researcher used an essay to know the students' writing proficiency specially in writing recount text because it measured the writing proficiency of the students. Thus, teacher determined four topics to be chosen by the students. The topics provided were about recount text. The topic chosen by the students was explored into an essay specially recount text which had been taught before in the classroom. From that essay, the researcher measured the writing proficiency of the students and calculated the result to know the effectiveness of the technique applied to teach writing.

Construct validity means that what the test ordered in accordance with the ability which wanted to be measured. In this case, the researcher ordered the students to write an essay because the researcher wanted to measure the ability of the students' writing especially in recount text. So, the product of this was writing, especially writing recount text.

Seeing from two validity item, content and construct, it can be conclude that the instrument was valid. The reliability of the test was computed using Pearson Product Moment formula because it is to find the correlation between rater 1 score and rater 2 score. The result is as follows:

Table. Rater Reliability

\section{Correlations}

\begin{tabular}{ccc} 
& AT & AT \\
& ER & ER \\
& 1 & 2 \\
\hline Pea & & \\
\hline
\end{tabular}




\begin{tabular}{|c|c|c|c|}
\hline A & rson & & 904 \\
\hline $\mathrm{T}$ & Correlation & & $\left({ }^{* *}\right)$ \\
\hline$E$ & & & \\
\hline$R$ & (2-tailed) & & 000 \\
\hline \multirow[t]{3}{*}{1} & $\Lambda$ & \multirow{3}{*}{6} & \\
\hline & & & 6 \\
\hline & \multicolumn{2}{|c|}{ Pea } & \\
\hline A & rson & 904 & \\
\hline $\mathrm{T}$ & Correlation & $\left({ }^{* *}\right)$ & \\
\hline$E$ & \multicolumn{2}{|c|}{ Sig. } & \\
\hline$R$ & (2-tailed) & 000 & \\
\hline \multirow[t]{2}{*}{2} & \multirow[t]{2}{*}{$\mathrm{N}$} & & \\
\hline & & 6 & 6 \\
\hline
\end{tabular}

The teacher made test can be reliable if the value of correlation is 0.904 . The significance is $0.000(\mathrm{p}<0.008)$. That shows the significant correlation between score given by rater 1 and 2 . Because there correlation is high enough, the test used in this research is reliable.

The data analysis is a concrete effort to make the data reliable, to know the differences of value method and well organized the data. Data analysis which was used here was statistical calculation and each data were formed into grouped data. Writing proficiency test of retelling class and control class provided the score of students' writing proficiency. This data analysis helped knowing the differentiation result between students' score of writing proficiency taught by using writing diary technique and those who are not. The data are analyzed by using Ancova because the design is quasi-experimental design. After knowing the result, the hypothesis testing was conducted. From SPSS Ancova table, the significance is noticed. If the significance level shows more than 0.050 ( $>>0.05)$, it means that data cannot reject null hypothesis, so null hypothesis is accepted. If the significance value shows lower than $0.05(\mathrm{p}<0.05)$, it means that data can reject null hypothesis, so alternative hypothesis is accepted. 


\section{Finding and Discussions}

In this case the researcher described for the mean, range sum, standard error of post-test, standard deviation, median, mode, minimum and maximum score in post-test and summary score of post-test. Descriptive Statistic of UAS Score (Covariate) UAS score was used as covariate. The descriptive statistic is stated below:

\begin{tabular}{lll}
\hline $\mathrm{N}$ & Valid & \\
& &
\end{tabular}

Missing

Mean

Std. Error of Mean

Median

Mode

Std. Deviation

Range

Minimum

Maximum

Sum 
Based on the table above, the researcher found that the mean of UAS score is 74.39 . Standard error of mean in experimental group is 2.059 . The median found is 78.00 , while mode is 85. Standard deviation is 13.967 . The range for UAS score of both classes is 55 . The minimum score 40 and the maximum score is 95 . And the summary score is 3422 .

After computing descriptive statistic, the homogeneity is computed. It is used to find the similarity of achievement between two groups.

\begin{tabular}{llll}
\hline ev & & & \\
en & & & \\
e & & & \\
St & & & \\
ati & & & \\
sti & & & \\
c & f1 & & \\
& & & \\
\hline 005 & & 4 & 944 \\
\hline
\end{tabular}

The table shows that the result of homogeneity test is 0.005 . The significance is 0.944 . It is higher than 0.05 ( $p>0.05)$. It means that both classes has similar ability in writing before being taught using writing diary technique.

Descriptive Statistic of Experimental Class Statistics

Descriptive Statistic Experimental class 
Mean

Std. Error of Mean

Median

Mode

Std. Deviation

Range

Minimum

Maximum

Based on the table above, the researcher found that the mean post-test of experimental class test is 81.73 . Standard error of mean in experimental group is 1.592 . The median found is 82.50, while mode is 90 for experimental class. Standard deviation is 8.117. The range for experimental class is 25 . The minimum score for experimental class in post-test is 65 and the maximum score is 90 . And the summary score for experimental class in post-test is 2125 .

Frequency Data Experimental Class

requ alid umulativ




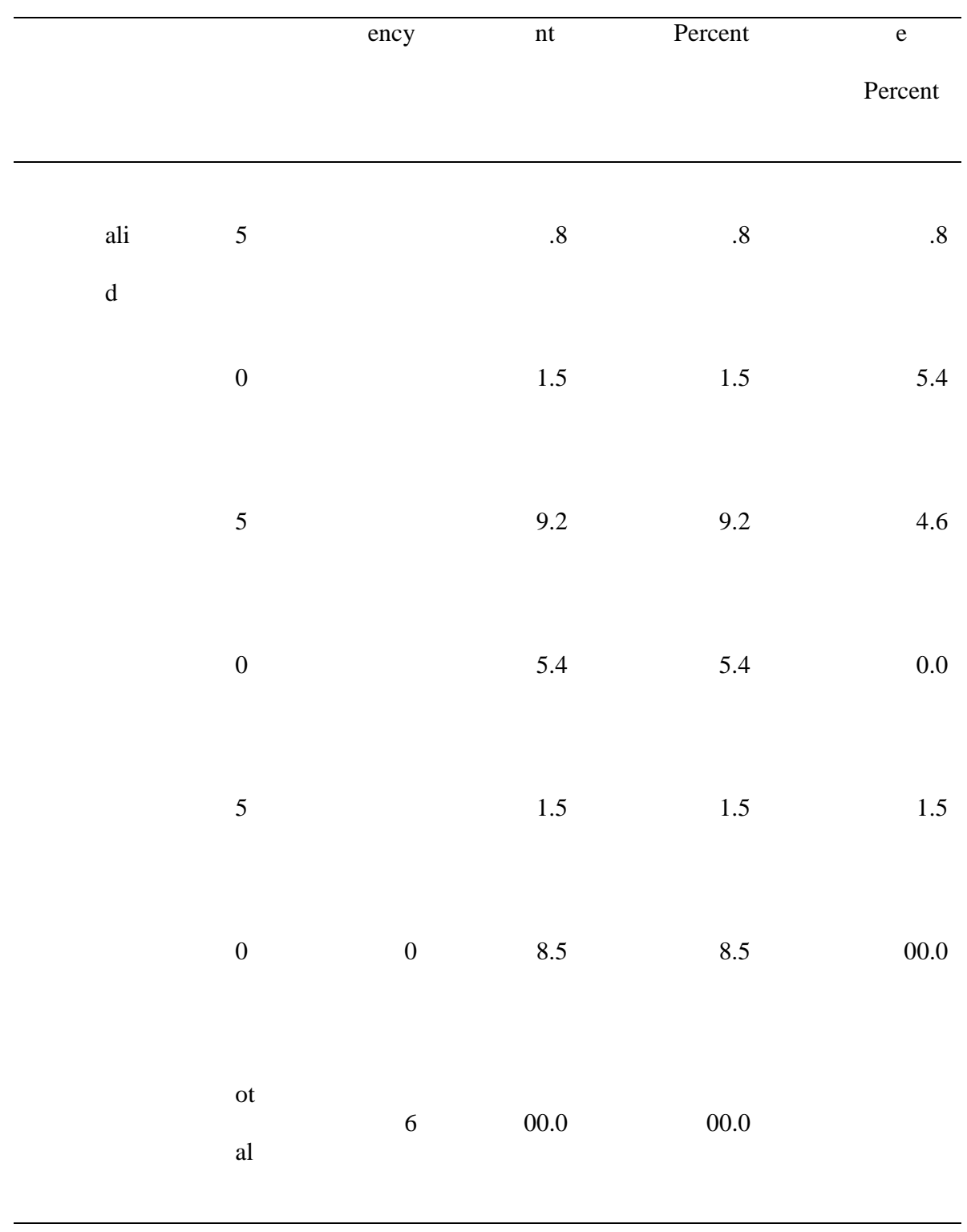

From the data above, it can be seen that the students got 65 are 1 student, the students got 70 are 3students, the students got 75 are 5 students, the students got 80 are 4 students, the students got 85 are 3 students, the students got 90 are 10 students. This data is from experimental class.

Normality data Experimental Class

One-Sample Kolmogorov-Smirnov Test

Experi

mental

N 


Normal Mean
Parameters(a,b)

Parameters(a,b)

Std.

Deviation

Most

Extreme

Differences

Absolu

te
Positiv

e

Negativ

e

Kolmogorov-Smirnov Z

Asymp. Sig. (2-tailed)

\footnotetext{
a Test distribution is Normal.

b Calculated from data.
}

If value in Assymp. Sig. (2-tailed) shows more than 0.05, the data are in normal distribution. Assymp.Sig. (2-tailed) shows 0.126 .it is higher than 0.05 (0.126>0.05), so it can be concluded that data in experimental class is in normal distribution.

Descriptive Statistic of Control Class

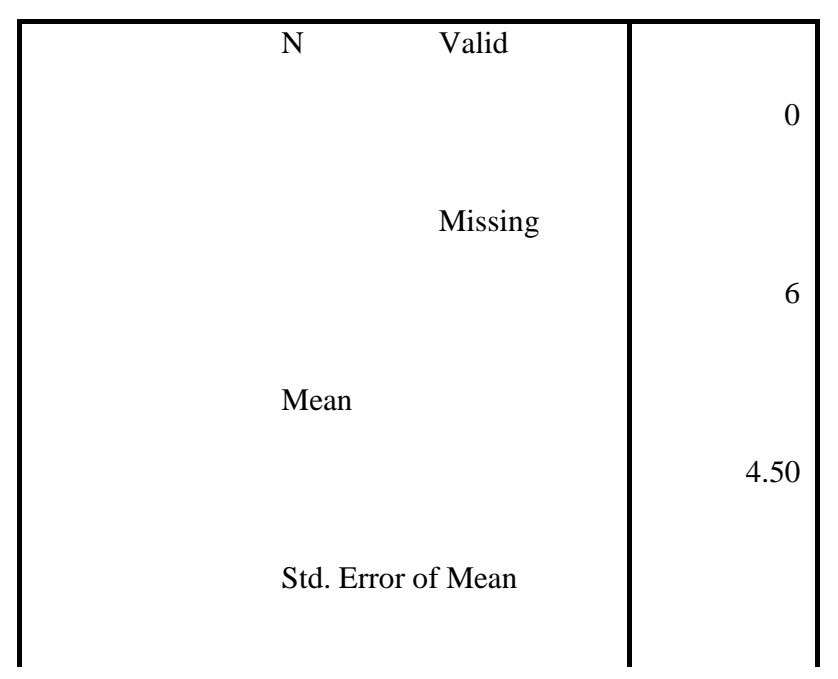




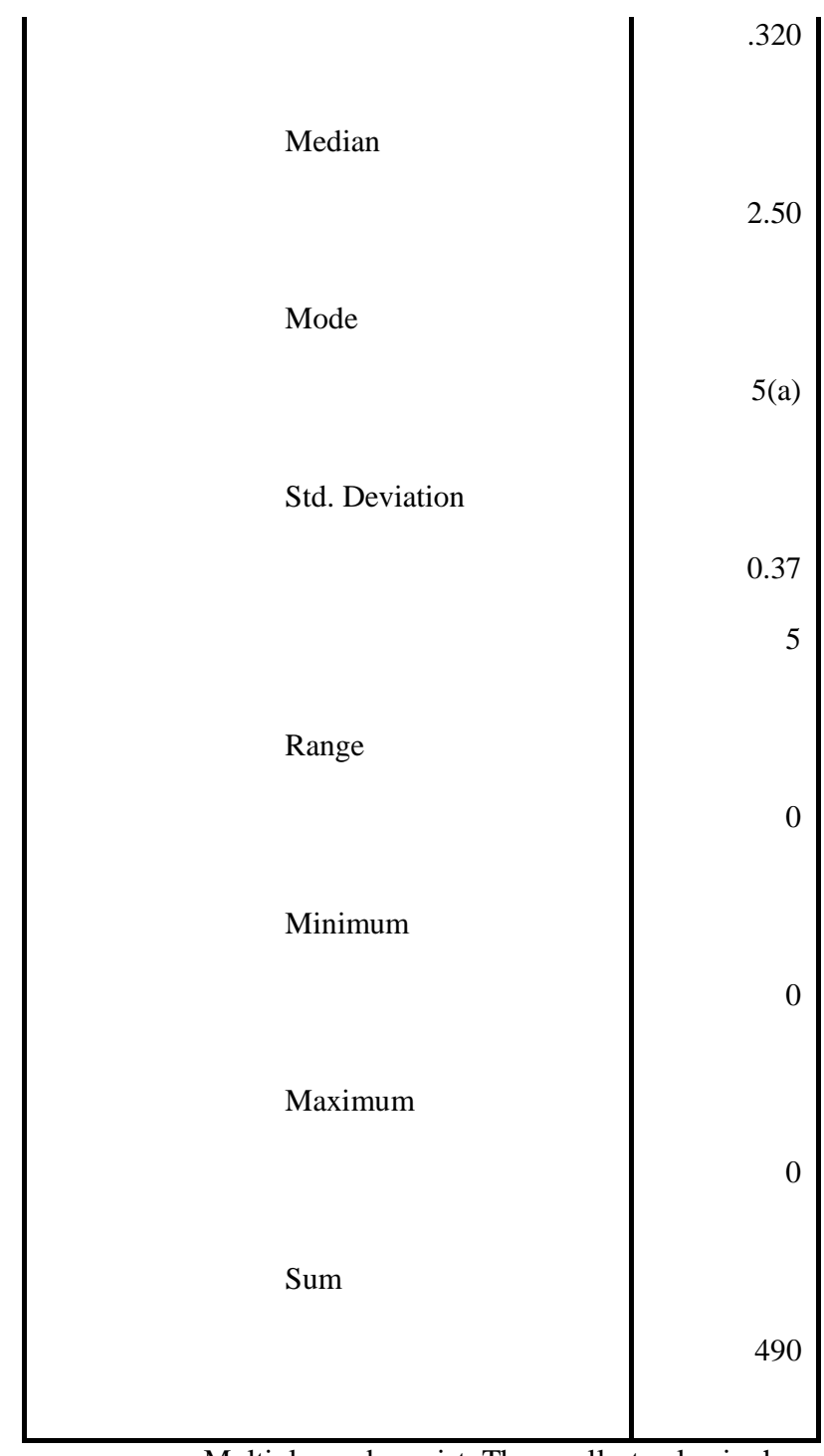

a Multiple modes exist. The smallest value is shown

Based on the table above, the researcher found that the mean post-test of experimental test is 74.50. Standard error of mean in experimental group is 2.320 . The median found is 72.50 , while mode is 65 for experimental class. Standard deviation is 10.375 . The range for experimental class is 30. The minimum score for experimental class in post-test is 60 and the maximum score is 90 . And the summary score for experimental class in post-test is 1490 . It shows that the students who get score 60 are 2 . The students got 65 are 4 students, the students got 70 are 4 students, the students got 75 are 4 students, the students got 85 are 2 students, the students got 90 are 4 students.

\section{Data of Control Group}

\begin{tabular}{ccccc}
\hline requ & erce & alid & \\
ency & nt & Percent & umulati \\
& & & & ve \\
\hline
\end{tabular}




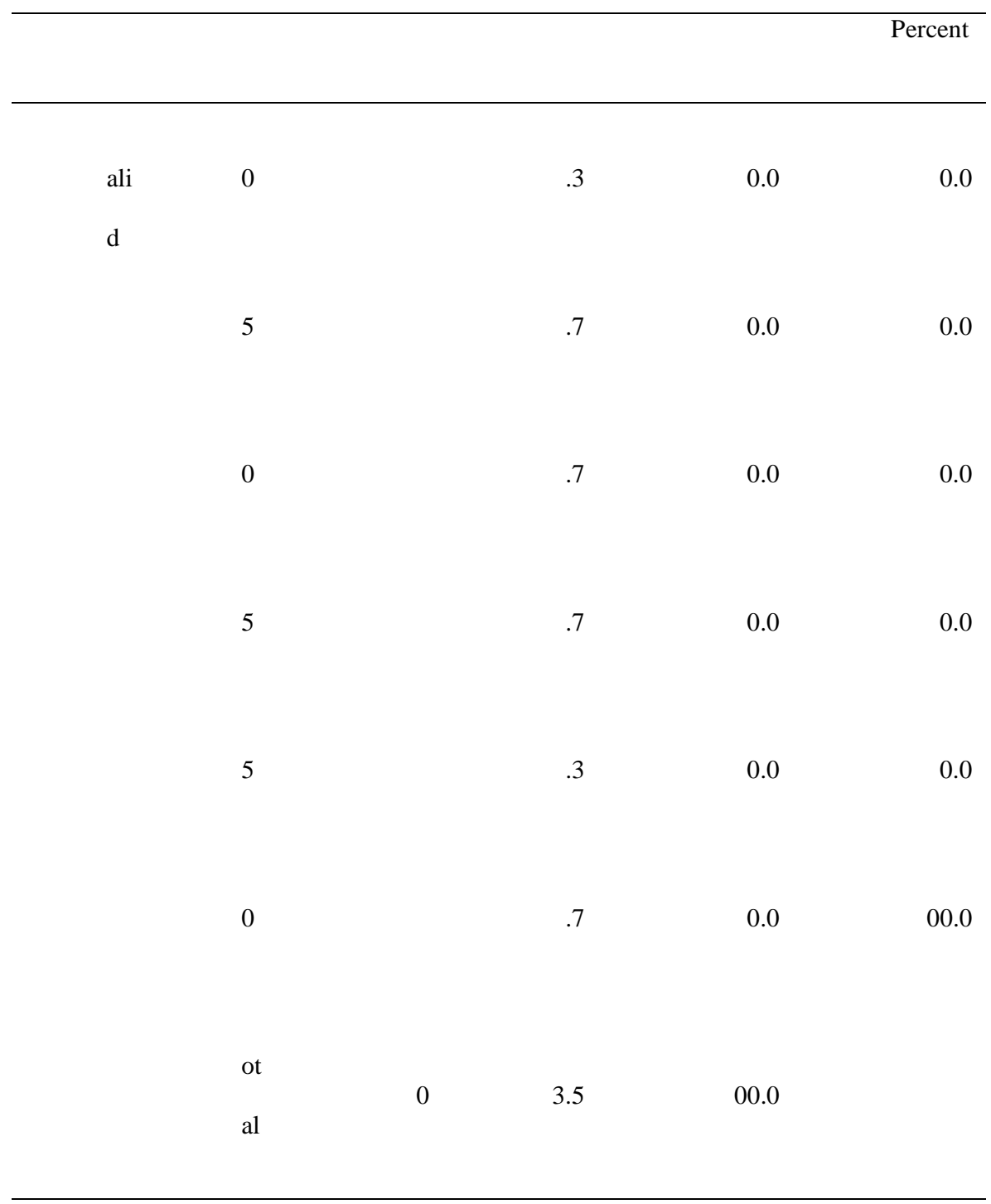

One-Sample Kolmogorov-Smirnov Tes

ontr

ol

$\mathrm{N}$

Normal

Mean

Parameters(a,b)

Std. Deviation

Most Extreme

Absolute

Differences

Positive 
Negative

Kolmogorov-Smirnov Z

Asymp. Sig. (2-tailed)

a Test distribution is Normal.

b Calculated from data.

The value of Asymp.Sig. (2-tailed) shows0.530.it is higher than 0.05. it can be concluded that the data of control class is distributed normally.

After finding descriptive analysis, the next step is testing the hypothesis by using Ancova computation. Ancova is used for testing whether there is significant difference between control and experimental class. The result is served as follows:

The Total of Subject

\begin{tabular}{lll}
\hline & alue \\
& Label & \\
& & \\
\hline$e$ & RITIN & \\
$\mathrm{t}$ & $\mathrm{G}$ & 6 \\
$\mathrm{~h}$ & JOUR & \\
0 & NAL & \\
$\mathrm{d}$ & & \\
& ON- \\
& WRIT & \\
& ING & \\
& JOUR & \\
& NAL \\
\end{tabular}


The table above shows the number of students being taught by usingwriting journal technique and non-writing journal technique. The students being taught using writing journal technique is used as experimental class amounted 26, while control class is amounted 20 students.

\section{Tests of Between-Subjects Effects}

\section{Dependent Variable: Post Test}

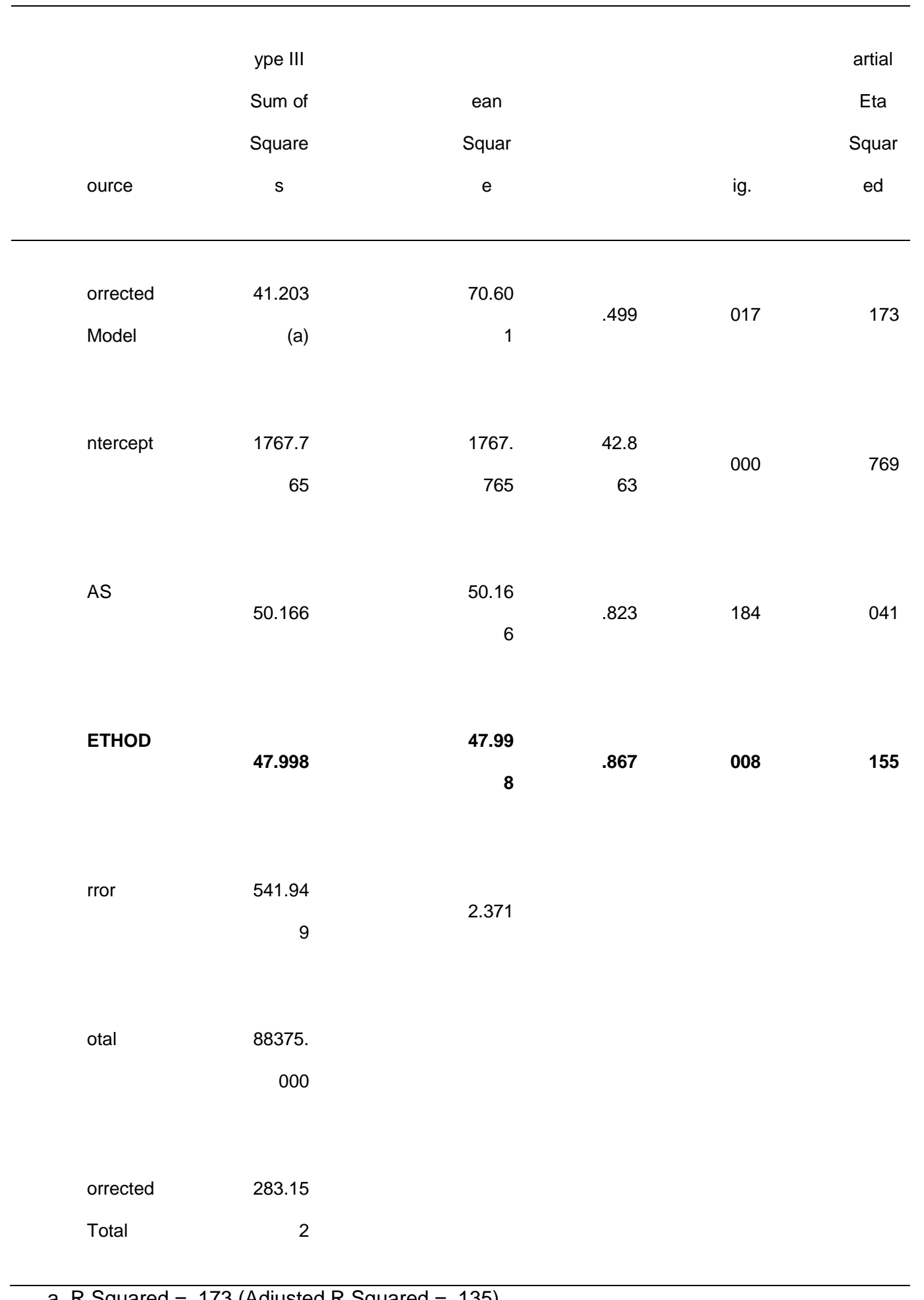


It can be seen the value of F ofMethod is 7.867 . The sig. shows 0.008 . The significance is lower than $0.05(0.008<0.05)$. if the significance value is lower than 0.05 , it can be concluded that the data can reject null hypothesis, so the alternative hypothesis is accepted. It means that there is significant difference between students who are treated by using writing journal technique and those who are not.

\section{Parameter Estimates}

Dependent Variable: Post Test

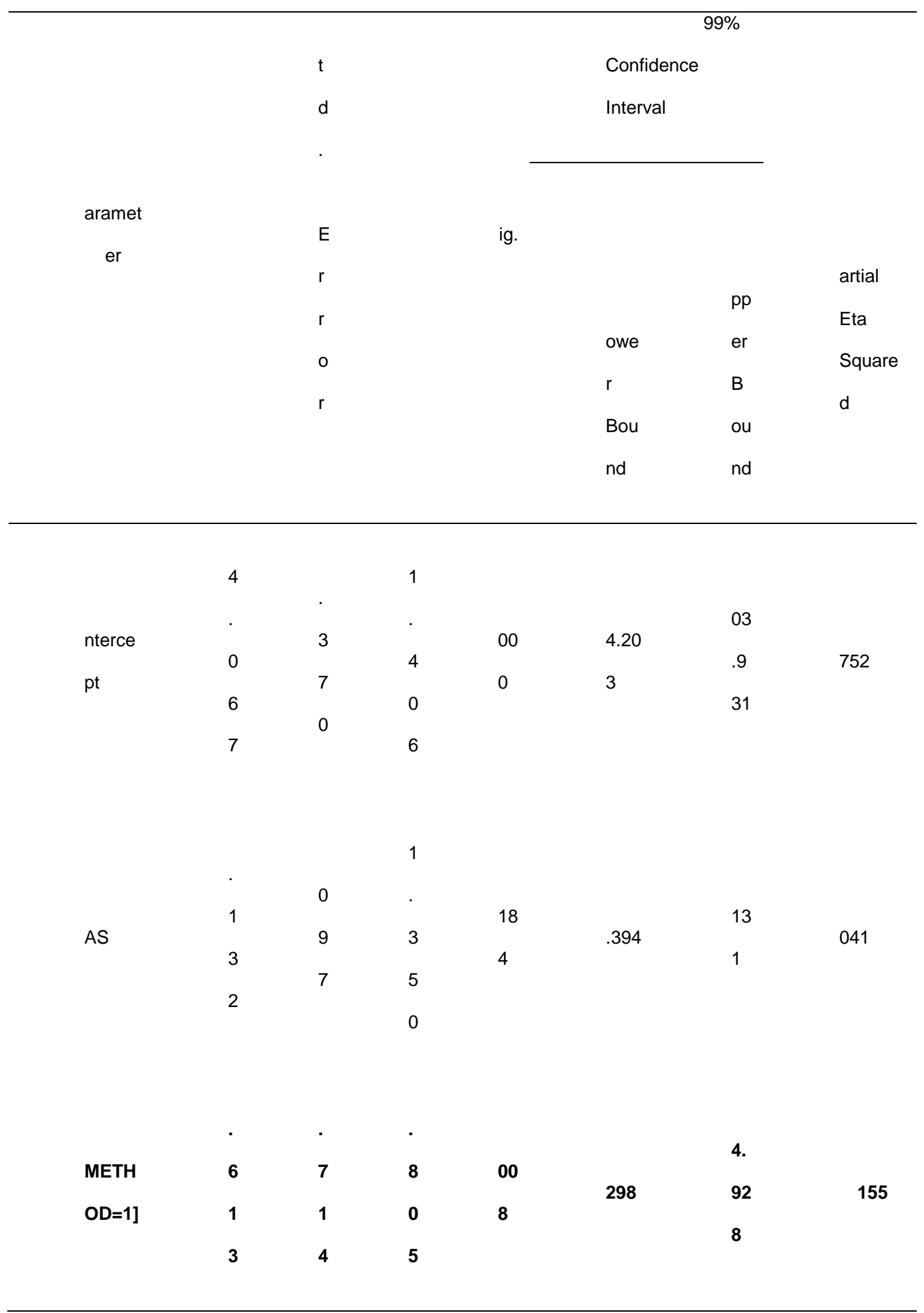




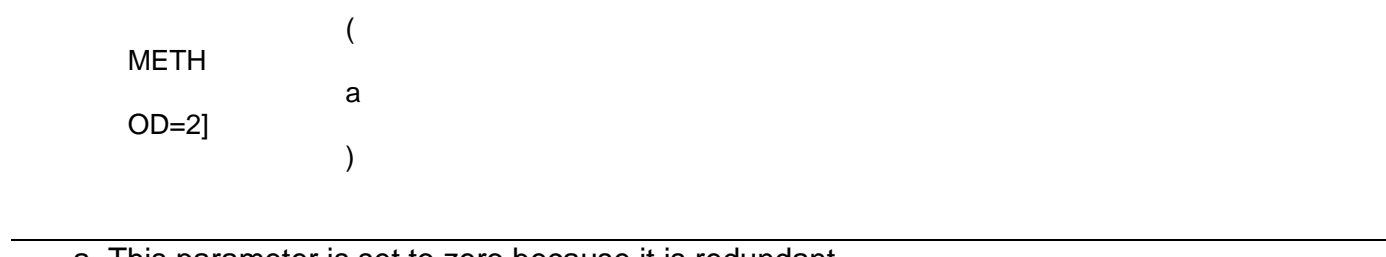

a This parameter is set to zero because it is redundant.

To find whether the method is effective or not, the parameter estimates is computed. The result of $\mathrm{t}$ is 2.805 . The sig. shows 0.008 . The significance is lower than $0.05(0.008<0.05)$. It means that the method is effective. The conclusion is writing journal technique and feedback is effective to teach writing.

According to Harmer (2004:125) journal is a log (or "account") of one's thought, feelings, reactions, assessments, ideas, or progress toward goals, usually written with little attention to structure, form, or correctness. Based on that explanation above about journal, journal is equivalent as diary. Writing daily activities, expressing thought and ideas, being assessment for learners is some of the goals in writing journal. This activity is kind of interesting thing because learner can articulate their thought without the threat of those thought being judge later by the teacher. So that is why, students prefer writing journal to writing essay because it is more freely to express the students' thought.

Feedback is information provided by an agent (e.g. teacher, peer, book, parents, and expertise) regarding aspects of one's performance or understanding. Feedback has three major questions, those are; a) where am I going? b) How am I going? And c) Where to next?. According to Hattie and Timperley (2007), to be effective, feedback needs to be clear, purposeful, meaningful, and compatible with students' prior knowledge and to provide logical connection.

Based on the findings of the study, the researcher concludes that increasing students writing proficiency by writing journal and giving feedback is effective applied in the classroom. Looking at the benefits of writing journal, it can be seen that this technique is very useful to teach writing, especially in recount text. Journal allows the students to express feelings more freely than they might do in public, the students just need to write down on their diary book and the access of it is only the teacher and the learners themselves. If journal writing is successfully encourage - and if the conditions for journal writing are appropriate - it has a powerful effect upon their motivation too, quite apart from promoting learner autonomy in writing( according to the book How To Teach 
English). Students have their own decision to express their thoughts and ideas, and it makes the students motivated to write freely.

Journal is kind of assessment but not test. It is the process to know the progress of students' writing skill. It aims to improve students' writing proficiency. the teacher can monitor the progress of their students in writing proficiency specially in recount text by following the students' journal writing. Teacher can respond and correct the students' writing in private; from this it will build the relationship between the teacher and the students closer. It can create the dialogue between the teacher and the students, of course in professional relationship still, and it help the teacher knowing the students' need so the teacher can determine the appropriate technique used in the classroom. Writing journal is habit activity, making something habit will improve our skill in that domain. By writing journal, it is expected that students can improve the writing proficiency. Journal writing contributes to a student's general writing improvement in the same way as training enhances an athlete's performance: it makes them fit (according to How to Teach Writing page 127). It states clearly that journal writing helps the learner to encourage students' writing proficiency, because it is done regularly so the students can practice their writing proficiency regularly.

Giving feedback after students did the works is effective to build the good relationship between teacher and students. Having good relationship with students will know what the students' needs. Teacher can provide the technique and material what students need. According to Hattie and Temperley (2007) effective feedback should provide information that helps students to see "where they are going" (learning goals); feedback information that tells students " how they are going”, and feed forward information that points out to students "where to go next". It means that the feedback which is given to students should give a measured data. The teacher should give a clear information about the goal of teaching learning process, especially in writing, then teacher should show how to solve the problem of students had, and the last, teacher will accompany students to go to the next step which shows an improvement and achievement of students' work.

Peterson (2011) also stated that to support students' sense of ownership of their writing, feedback should be designed as follows: be given in the spirit of showing student writers the positive effects their writing has on readers, identify potential areas where students may revise their writing to clarify meaning or more fully engage readers, take the form suggestions, observations, 
and open-ended questions, rather than instructions and criticism. From those statements before, teacher can correct the students' work appropriately, and learners' can correct their work after being given feedback by the teacher.

Based on the result, all the theory mentioned above and the previous research conducted before shows that the results of all are proven in this research. By writing journal, the students can habituate in writing especially in recount text. The can produce writing easily and lack of mistakes. As well as also with giving feedback to the students' work, the students' work becomes better and better. It helps them to know their mistakes in writing, so they can improve it better. Therefore, it can be concluded that the learners has a good achievement in writing proficiency by making habit their writing by writing journal and giving feedback. The test instrument covered the skills that required above, and the post-test result showed that students' taught by using writing journal technique and giving feedback have better achievement than who are not taught by using writing journal technique and giving feedback. It might be concluded that writing journal technique and giving feedback was a good technique for the students in supporting learning writing.

This result of research shows that writing journal technique and feedback gives positive effect toward students' writing achievement better than students' who are not taught by using this technique, same as the some previous researches. It gives much opportunity to students to explore their skill in writing become well.

\section{Conclusion}

After doing the research, in accordance with the using of writing journal technique and giving feedback to increase students' writing proficiency, the researcher concludes that: The students after being taught by using writing journal technique and giving feedback have better achievement than who are not taught by using writing journal technique and giving feedback in the post-test at the first level of IAIN Kediri. By using this technique, students can explore their expression, thought, feeling, idea, and etc. into their writing. Students will feel free to express their feeling without feeling judged. Teacher can build the good relationship with the students by giving feedback after the students write their journal. From this activity, teacher and students will recognize what their need and want. 
The hypothesis testing stated that teaching writing by using writing journal technique and giving feedback have a significant effect on the student' writing proficiency achievement at the first level of IAIN Kediri. It was proved from the computation of F-Value was higher than critical Fvalue on level significance 0.008 . Based on this result, it means that teaching writing by using writing journal technique and giving feedback to increase students' proficiency gave any significant effect on the students' writing proficiency achievement at the first level of IAIN Kediri.

\section{References}

Allman, Barbara. 2000. Skills for Successful Teaching: Mc. Graw-Hill Children's Publishing.

Alwasilah, Chaedar. 2004. Perspektif Pendidikan Bahasa Inggris di Indonesia dalam Konteks Persaingan Global. Bandung: Andira

Brown, Doughlas. 2000. Teaching by Principles an Interactive. San Fransisco: Longman

Crystal,David. 1997. The Cambridge Encyclopedia of Language. Cambridge: Cambridge University Press.

Depdiknas. 2006. Kurikulum Tingkat Satuan Pendidikan. Jakarta

Depdiknas. 2006. Peraturan Menteri Pendidikan Nasional, No. 22 Tahun 2006 Tentang Kerangka Dasar dan Struktur Kurikulum SMP/MTs. Jakarta

Ellis, Rod. 2009. Analyzing Learner Language. New York: Oxford

Hadfield, Jill \& Hadfield, Charless. 2008. Introduction to Teaching English.: Oxford University Press

Harmer,Jeremy.2007 .How to Teach English. Chine: Pearson Education Limited

Harmer, Jeremy.- .The Practice of English Language Teaching. U.K.: Pearson Education Limited

Hattie, John. 2008. Visible Learning. London :Rouledge 
Hattie, John, \& Timperley, Helen. 2007. The Power of Feedback. American Education Research Association and SKGE.

Pertiwi, Indri Eka .2013 .Teacher's Feedback on Students' Descriptive Texts : A Case Study Conducted in A Junior High School in Bandung. Universitas Pendidikan Indonesia: respository.upi.edu

Peterson, S. \&Mc. Clay, J. 2010. Assessing and Providing Feedback for Students Writing in Canadian Classroom Assessing Writing.

Saville\&Troike. 2006. Introducing Second Language Acquisition. New York: Cambrige University Press

Scrivener,Jim. - . Learning Teaching. : Macmillan Books for Teachers

Swan, Michael. 1994. Practical English Usage. Great Britain: Oxford University Press.

Whitehouse, George E. 1986. Understanding the New Technologies of the Mass Media. New Jersey: Prentice-Hall

Wishon, George E, \& Burks, Julia M. 1994. Let's Write English Revised Edition. New York: Litton Educational Publishing Inc. 